\title{
Neuralgia, Neurology, Neuro-
}

\author{
J.M.S. Pearce \\ Emeritus Consultant Neurologist, Department of Neurology, Hull Royal Infirmary, Hull, UK
}

There are many named neuralgias familiar to physicians, far too many to list. Neuralgia is defined as a pain, typically stabbing or burning, in the area served by a nerve; also an instance, type, or case of this.

The word comes from neuro- +-algia. Neuro- in Greek was a sinew, tendon or nerve, cognate with classical Latin nervus. In Greek algos is pain. Neuralgia derives from usage in French: névralgie (appears first in 1690). John Fothergill described trigeminal neuralgia in 1773 [1], but did not name it neuralgia. An early English use of "neuralgia' was in Edinb Med Surg $J$ 1807;3:15:'This is evidently a case of Neuralgia (tic douloureux) produced by an injury of a branch of the musculo-cutaneous nerve' [sic].

At that time the name neuralgia constituted a genus of neuroses, and Nicolas André's term tic douloureux (1756) was evidently used to describe a variety of neuralgias.

Neuralgia is pain deriving (directly) from a nerve or nervous tissue; it usually refers to one specific anatomical determinant such as trigeminal neuralgia. But sometimes it relates to the predisposing cause, e.g. postherpetic neuralgia, and sometimes eponymously to the person who described the condition, though not always the first to do so: for example Sluder's neuralgia.

It has been applied wrongly to ill-defined unexplained aching pains of uncertain cause, often in the past to nonarticular 'rheumatic' pains and aches. When we talk of neuralgic pain deriving from an irritative, inflammatory or compressive lesion of the nerve, we should refer to the deep, often intensely painful stabbing, sharp or boring quality of pain, often with extremely unpleasant accompanying burning or cold sensation. Painful dysaesthesiae may or may not accompany it, especially in causalgia Greek kausos ('heat, fever') + algos ('pain').

Neurology and neurologist are of similar origins: from the Greek (neuro-logia). Thomas Willis [2] first employed the word neurology in Cerebri Anatome (1664) in a Latin context: "by the cense or numbering of the Nerves, being particularly made, we should deliver an exact Neurology or Doctrine of the Nerves'. Neuro- was earliest shown in words such as Neurology - of Greek origin - in the 17th century, and in the 18th and early 19th century in loanwords from post-classical Latin, e.g. neurosis, neurotomy, and neuralgia. Dozens of combining forms permeate the medical literature: neurocognitive, neuroarthropathy, neurocutaneous, neurofilament, neurodegenerative and so forth.

Be careful with the different forms resembling the suffix -algia! In Greek algetic- is to feel pain, but algorithm or algorism have origin in the Greek aritmos meaning number. In Latin, algor is cold or chilly; but alga in Latin is confusingly a seaweed and hence algae.

$\begin{array}{ll}1 \text { References } & \begin{array}{l}\text { Fothergill J: Of a painful affection of the face. } \\ \text { Medical observations and inquiries by a soci- } \\ \text { ety of physicians. London } 1773 ; 5: 129-142 .\end{array} \\ & \text { [This publication was funded privately by } \\ & \text { Fothergill from 1771-1776. It is included in } \\ & \text { the 'Complete Works of John Fothergill', a } \\ & \text { copy in library of RCP London]. } \\ 2 & \text { Willis T: Cerebri Anatome (1664) xix:133, } \\ & \text { translated into English by Pordage S: Remain- } \\ & \text { ing medical works tr. 1681. }\end{array}$

J.M.S. Pearce

304 Beverley Road

Anlaby, East Yorks HU10 7BG (UK) 